\title{
Long-term land subsidence and strata compression in Changzhou, China
}

\author{
G.Y. Wang ${ }^{\mathrm{a}, \mathrm{c}}$, G. You ${ }^{\mathrm{b}, *}$, B. Shi ${ }^{\mathrm{a}}$, J. Yu ${ }^{\mathrm{c}}, \mathrm{M}$ Tuck $^{\mathrm{b}}$ \\ a Department of Geoscience, Nanjing University, Nanjing 210093, China \\ b School of Science and Engineering, University of Ballarat, Ballarat 3353, Australia \\ c Geological Survey of Jiangsu Province, Nanjing 210018, China
}

\section{A R T I C L E I N F O}

\section{Article history:}

Received 30 November 2007

Received in revised form 7 August 2008

Accepted 3 September 2008

Available online 16 September 2008

\section{Keywords:}

Borehole extensometer

Changzhou

Groundwater drawdown

Groundwater extraction

Land subsidence

Strata compression

\begin{abstract}
A B S T R A C T
Changzhou City, underlain by a multi layered aquifer system in Quaternary sediments in the Great Yangtze River Delta region, experienced a maximum land subsidence rate of $147 \mathrm{~mm} / \mathrm{year}$ in the early 1980s due to excessive groundwater extraction. A large scale monitoring station of 11 borehole extensometers was established in the city in 1983 to investigate land subsidence. Nine strata were predetermined in the Quaternary depth interval and monitored by borehole extensometers. Presented in this paper are the long term observations of land subsidence, strata compression and groundwater level in four aquifers from 1984 to 2002, and discussion on strata compression based on the measured data with reference to the stratigraphy, soil properties, groundwater withdrawn and literature of similar situations. The compression of strata varies significantly and is strongly influenced by groundwater drawdown in the second confined aquifer, or CA2. The groundwater level in CA2 declined from -55 m in 1981 to -76 $\mathrm{m}$ in 1994 and the land subsidence rate remained high. After the city government enforced restrictions on groundwater extraction in 1995, the extraction rate sharply reduced, the groundwater level in CA2 steadily recovered to $-56 \mathrm{~m}$ until 2003, and the land subsidence rate declined to $10 \mathrm{~mm} / \mathrm{year}$ in 2002. From 1984 to 2002, the land subsidence was mainly attributed to the consolidation of the thick aquitard overlying CA2. In the future, to prevent the subsidence rate from rising, it is vital to stop groundwater drawdown in aquifers.
\end{abstract}

(c) 2008 Elsevier B.V. All rights reserved.

\section{Introduction}

Land subsidence is a common phenomenon in the extractive industries, such as groundwater (Holzer and Johnson 1985; Abidin et al., 2001; Li et al., 2006), petroleum and mining (Singh, 1992). As it may cause geological, hydrogeological, environmental and/or economic impacts (Holzer and Johnson, 1985; Holla and Barclay, 2000; Abidin et al., 2001; Phien wej et al., 2006), land subsidence attracts much attention from government, community, industry and academia. Though it cannot be completely avoided in the extractive industries, land subsidence can be controlled more sustainably through governmental legislations, monitor ing, industrial plans and technological advances (Endo, 1992; Singh, 1992; Abidin et al., 2001; Hu et al., 2004; Zhang et al., 2007). This paper presents a case study of land subsidence caused by groundwater extraction in Changzhou City, China.

Land subsidence caused by groundwater exploitation in an urban area is not new in cities that depend on groundwater as an important water supply for human consumption and industrial utilization. In 1985, at least 17 cities in the world had the impact of land subsidence caused by groundwater withdrawal and eight of them experienced significant economic impacts which were summarized as inundation and flooding of coastal areas, large differential settlement, well casing failure, building "rising" and ground cracks (Holzer and Johnson, 1985). The phenom enon appears to be increasing in severity, for example in some heavily populated metropolises in Asia, such as Bangkok (Nutalaya et al., 1986; Phien wej et al., 2006), Jakarta (Abidin et al., 2001), Shanghai (Zuo et al., 1993; Hu et al., 2004; Zhang et al., 2007), Tianjin (Hu et al., 2002; Hu et al., 2004) and Tokyo (Endo, 1992). The impacts can be manifested to different extents in land subsidence areas, for examples, crack of permanent structures and expansion of flooding areas in Jakarta (Abidin et al., 2001); intensification of city flooding, regression of shoreline and building "rising" in Bangkok (Phien wej et al., 2006). Furthermore, additional impacts may occur over time, such as the intrusion of sea water inland (Abidin et al., 2001; Phien wej et al., 2006).

In China, land subsidence is a widespread challenge in many cities in addition to Shanghai and Tianjin. In 2004, there were 45 cities with disastrous land subsidence in China, and more than 11 of them had an accumulated subsidence greater than $1 \mathrm{~m}$ (Hu et al., 2004). Changzhou is among the 11 cities and is located in the Great Yangtze River Delta region. The Great Yangtze River Delta is a lowland area and most ground elevation is within $2.0 \mathrm{~m}$ to $8.0 \mathrm{~m}$ above sea level, where rapid growth in economy and population necessitate a greater demand for groundwater. As a result, severe land subsidence occurs in this region as reported in the case studies of Suzhou City (Chen et al., 2003) and Hangzhou (Li et al., 2006).

As a medium scale city with rapid economic development, Changzhou City has endured the impacts from land subsidence 


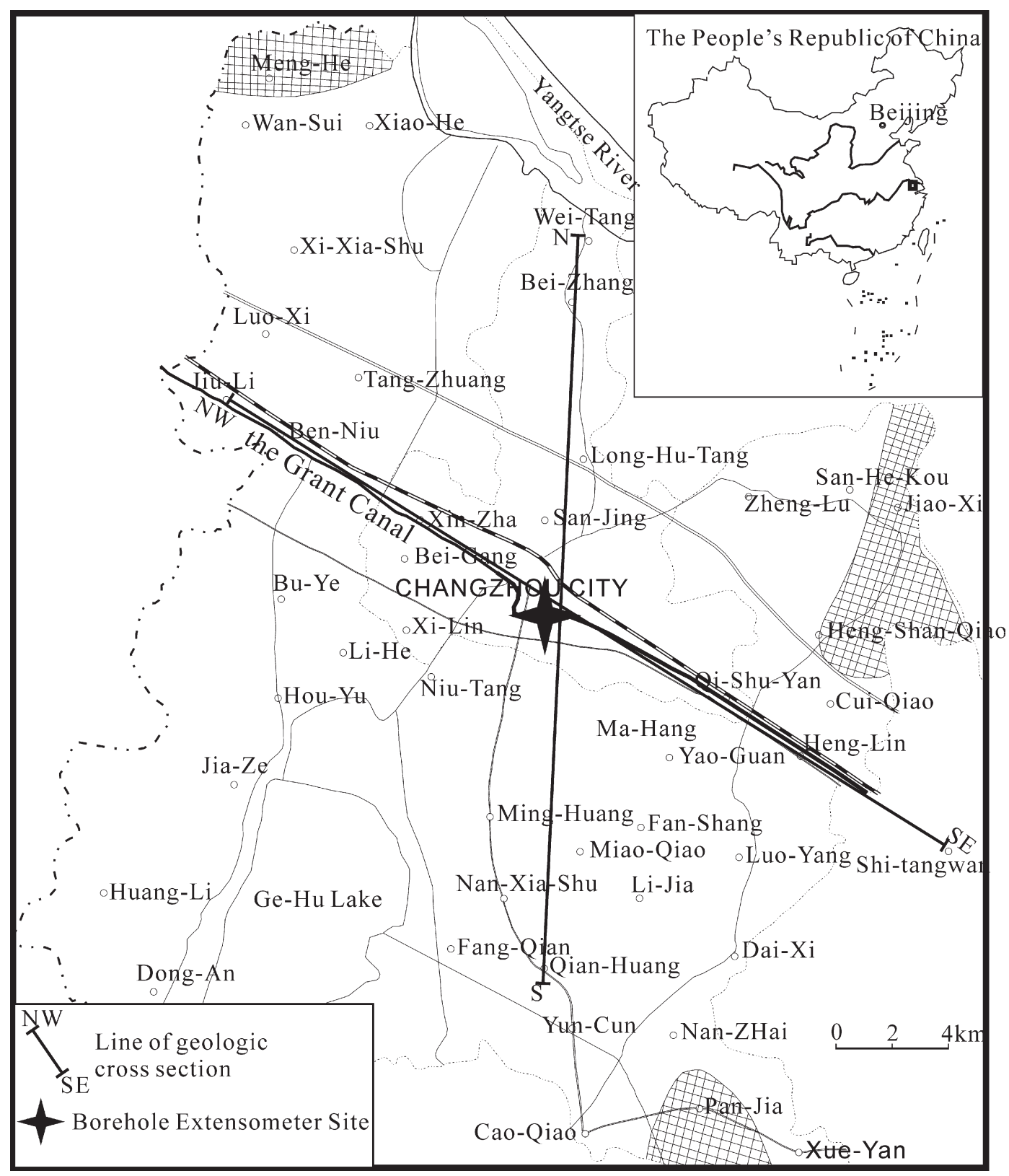

Fig. 1. Map of study area and location of borehole extensometer site in Changzhou City, China.

caused by excessive groundwater exploitation since the1970s. The City Government established a land subsidence monitoring station in 1983 to recognize the nature of land subsidence in Changzhou so that it can take strategic measures to alleviate land subsidence and to reduce the potential impacts. Importantly, the Changzhou City land subsidence monitoring station measures not only the gross settlement on ground surface, e.g. in Suzhou (Chen et al., 2003) and Hangzhou (Li et al., 2006), but also the settlements at various depths in Quaternary until bedrock at $163.8 \mathrm{~m}$ deep through 11 borehole extensometers. Therefore, the compression of each stratum, totally nine strata, can be assessed based on the settlements and groundwater level changes in aquifers.

\section{Regional geological and hydrogeological settings}

Changzhou City is located in the Southern Jiangsu Province with its north adjacent to the Yangtze River and its south to Tai Lake. The Grant Canal passes through the city along the railway (see Fig. 1) and Gehu Lake is on the southwest. Fig. 1 is a map of Changzhou and includes the location of the borehole extensometer site. The typical ground elevation is between $3.8 \mathrm{~m}$ to $7.0 \mathrm{~m}$ in Changzhou and it is $4.2 \mathrm{~m}$ to $4.5 \mathrm{~m}$ at the site. Fig. 2 depicts two geologic cross sections of the study area in NW SE and north south direction, respectively, and they cross at the borehole extensometer site.

Quaternary sediments of $120 \mathrm{~m}$ to $240 \mathrm{~m}$ thick are commonly presented in Changzhou, except for the sandstone and shale strata outcrops on the east, south and north that are marked as a grid in Fig. 1. There are four aquifers in the Quaternary alluviums, namely, one unconfined and three confined aquifers, which are denoted as UCA, CA1, CA2 and CA3, respectively. Conventionally, groundwater within $50 \mathrm{~m}$ deep is shallow, i.e. UCA and CA1, or otherwise is deep, i.e. CA2 and CA3.

\section{Groundwater exploitation and land subsidence in Changzhou}

\subsection{State of groundwater exploitation in Changzhou}

Groundwater exploitation in Changzhou City started in the 20th century, and the earliest deep well was dug in 1919. There were 18 

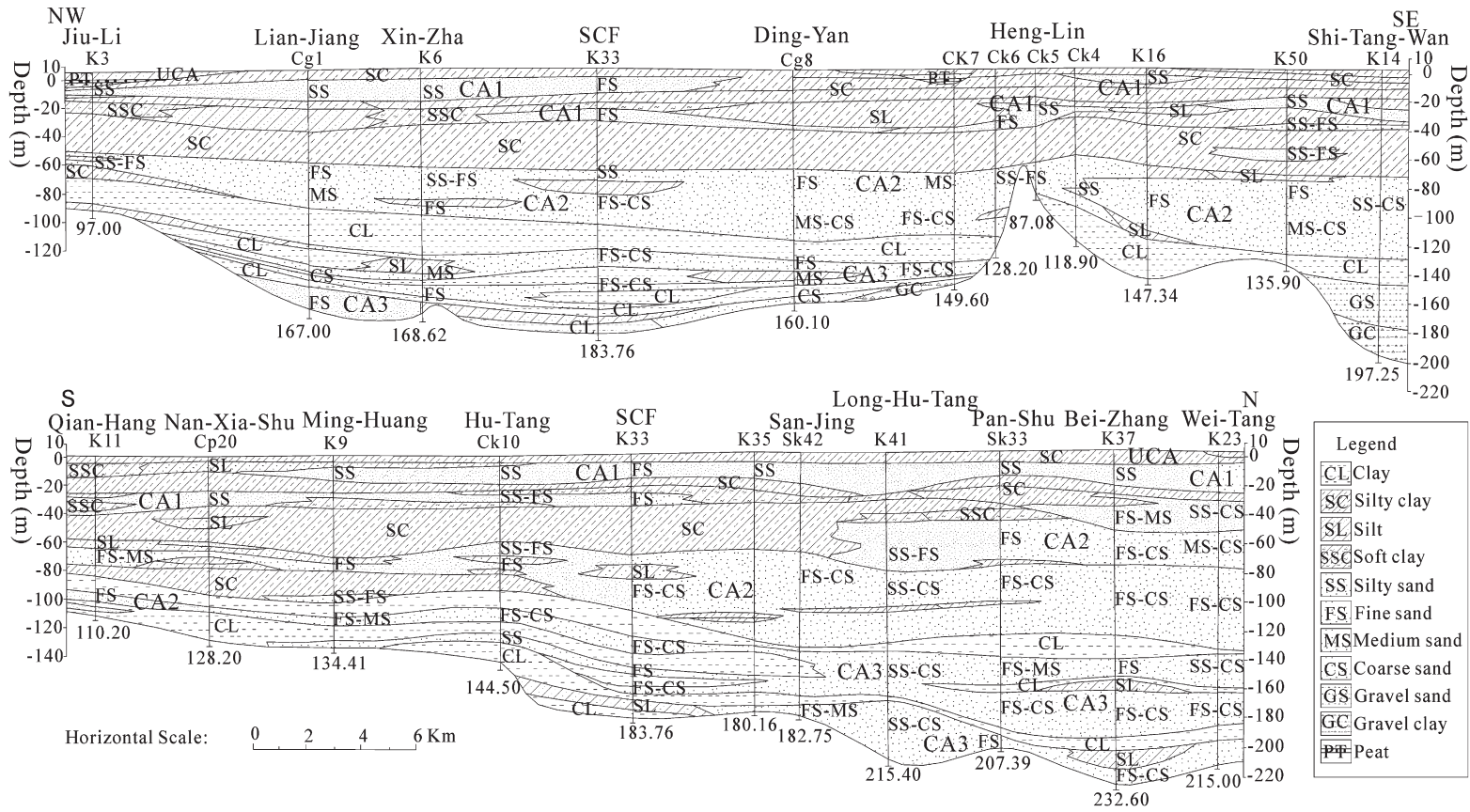

Fig. 2. Geologic cross sections passing the borehole extensometer site. 
Year

1984198619881990199219941996199820002002

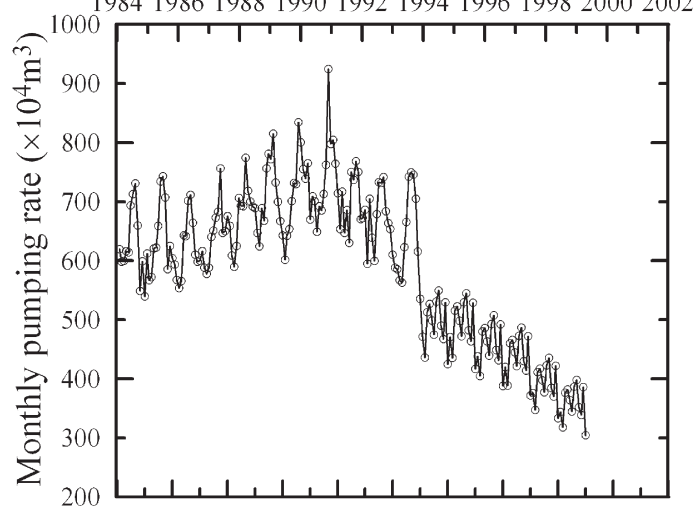

Fig. 3. Groundwater extraction rate in Changzhou from 1984 to 2002.

deep wells by early the1950s with an extraction rate of less than $3,650,000 \mathrm{~m}^{3} /$ year, and the groundwater level was close to the ground surface. For example, the groundwater level was just $0.6 \mathrm{~m}$ (The negative value means below sea level and the positive means above sea level in this paper.) near Dongfeng Printing \& Dyeing Factory (DPDF). It is believed that the original groundwater levels in all aquifers were about the same and near the ground surface in this region (Li et al., 2006). The number of deep wells has increased sharply since 1957, and the deep wells mainly pump groundwater from CA2. In the middle of the 1960s, the extraction rate increased to $40,000,000 \mathrm{~m}^{3} /$ year. By 1967 , the cumulative extraction was up to $300,000,000 \mathrm{~m}^{3}$, the groundwater level at the cone centre was $20 \mathrm{~m}$, and there was no significant land subsidence.

The cone of depression was small in Changzhou City in the early 1970s. The cone enlarged year after year with the increased annual extraction of groundwater. By the end of the1970s, the extraction rate exceeded $47,450,000 \mathrm{~m}^{3} /$ year, resulting in a state of excessive exploita tion (FHEG, 1984, 1989; GSJP, 2004). As the cone expanded, the ground water level lowered to $51.2 \mathrm{~m}$ in 1975 . Consequently, a significant land subsidence manifested by deep well protrusion and ground cracks around the wells.

The emerging local economy drastically increased the utilization of groundwater in the 1980s and accelerated the groundwater drawdown. In 1980 , there were 367 deep wells with a total annual extraction in excess of $100,000,000 \mathrm{~m}^{3}$. The average density of deep wells was $3.7 \mathrm{wells} / \mathrm{km}^{2}$, and it was 19 wells $/ \mathrm{km}^{2}$ in some areas. In 1981, the groundwater level at the cone centre reached $64 \mathrm{~m}$ and by 1994 it was down to $76 \mathrm{~m}$.

Since 1995, the city government has strengthened restrictions on groundwater extraction, and some deep wells have been sealed. The effect of this enforcement was manifested in the sharp reduction of extraction rates in 1995 and a steady decline since then as shown in Fig. 3, a gradual recovery of the groundwater level in CA2 as shown in Fig. 4, and a significant slowdown in land subsidence. By 2003, the groundwater level in CA2 recovered $20 \mathrm{~m}$ from its low in 1994 to $56 \mathrm{~m}$.

\subsection{State of land subsidence in Changzhou}

Land subsidence was first observed in Changzhou in the 1960s. By the end of the 1970s, well protrusion and ground cracks around wells were phenomenal; for instance, a deep well protruded $260 \mathrm{~mm}$. The First Hydrogeology and Engineering Geology of Jiangsu Province conducted five levelling surveys in Changzhou City from May 1979 to October 1983. As shown in Fig. 5, the solid line is the contour of cumulative land subsidence during this period and the dotted line is the contour of the groundwater level in CA2 in 1983. The area of land subsidence exceeded $200 \mathrm{~km}^{2}$ with its centre near DPDF; the average cumulative subsidence was $268.34 \mathrm{~mm}$ with a maximum of $558.17 \mathrm{~mm}$. The average subsidence rate was $6070 \mathrm{~mm} / \mathrm{year}$, and reached a maximum of $147 \mathrm{~mm} /$ year.

In the late 1980s, the land subsidence rate was maintained at $40 \mathrm{~mm} /$ year. Four land subsidence troughs were formed at DPDF, Post New Village (PNV), Changzhou Chemical Factory (CCF) and Eastern Suburb Park (ESP). In 1989, the troughs at DPDF and PNV merged with a land subsidence rate of $3040 \mathrm{~mm} /$ year as did the troughs at CCF and ESP with a subsidence rate of $4050 \mathrm{~mm} /$ year. By 1993, the cumulative subsidence of CCF ESP trough exceeded $1000 \mathrm{~mm}$ with an average subsidence rate of $5080 \mathrm{~mm} /$ year at the rapidly expanded south eastern part of the trough. Consequently, this trough became a major land subsidence area in Changzhou City that featured with a large area and magnitude of subsidence as shown in Fig. 6, where the dotted lines are the contours of cumulative subsidence from 1984 to 1993 and the solid line is the $500 \mathrm{~mm}$ contour in different years. The solid contour lines demonstrate a rapid expansion and mergence of land subsidence troughs; four small $500 \mathrm{~mm}$ contours in 1983 developed into a far larger one by 1993.

In fact, DPDF PNV and CCF ESP troughs had already merged in 1991 at the $500 \mathrm{~mm}$ contour (the solid contour line 1991 in Fig. 6). At present, a very large regional land depression zone has been formed beyond Changzhou City, which encompasses Changzhou City and the neighbouring Wuxi and Jiangyin cities, etc. The area with land subsidence of more than $200 \mathrm{~mm}$ has dramatically expanded; it is close to $10,000 \mathrm{~km}^{2}$ (Zhang et al., 2007). The area of subsidence beyond $800 \mathrm{~mm}$ is about $50 \mathrm{~km}^{2}$; the centre of the trough is at CCF with a settlement of more than $1,200 \mathrm{~mm}$ (refer to Fig. 6).

\subsection{Impacts of land subsidence in Changzhou}

The impacts of land subsidence observed in Changzhou City include well protrusion, ground cracks, decreasing clearance beneath bridges, increased flood threats and damages to the national survey benchmark, infrastructure and sewage drainages, etc. Well protrusion was found in 31 cases during an investigation of 175 deep wells in Changzhou City in 1978 1979. Ground cracks are common around the protruded wells in the city. Ground cracks associated with land subsidence triggered by groundwater withdrawal and coupled by the influence of special geological structures, such as Ancient Yangtze River Course that is part of CA2 locally and underlain in the north west of Changzhou City, are a geohazard in neighbouring areas (Wang et al., 2008). The ground cracks have caused damage to buildings and farmlands, and forced the villagers to evacuate in some cases (Zhu et al., 1993). Land subsidence has lowered the ground elevation, so the

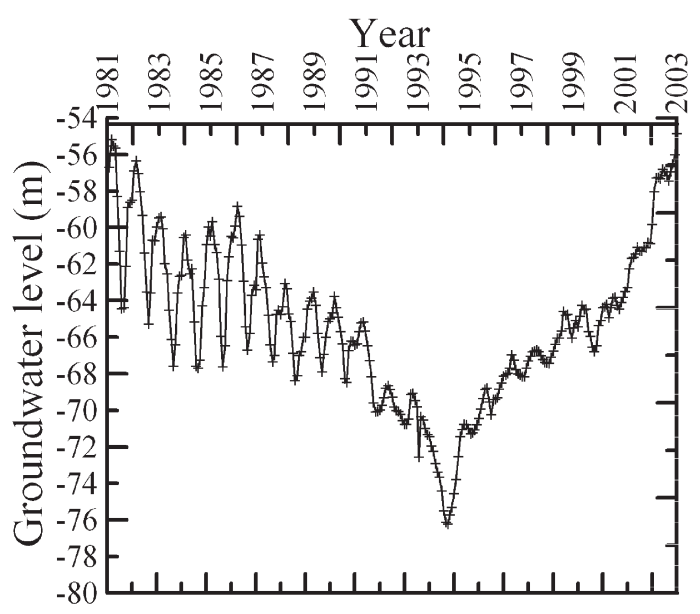

Fig. 4. Groundwater level in CA2 observed from the deep well at State Cotton Factory (SCF) from 1981 to 2003 


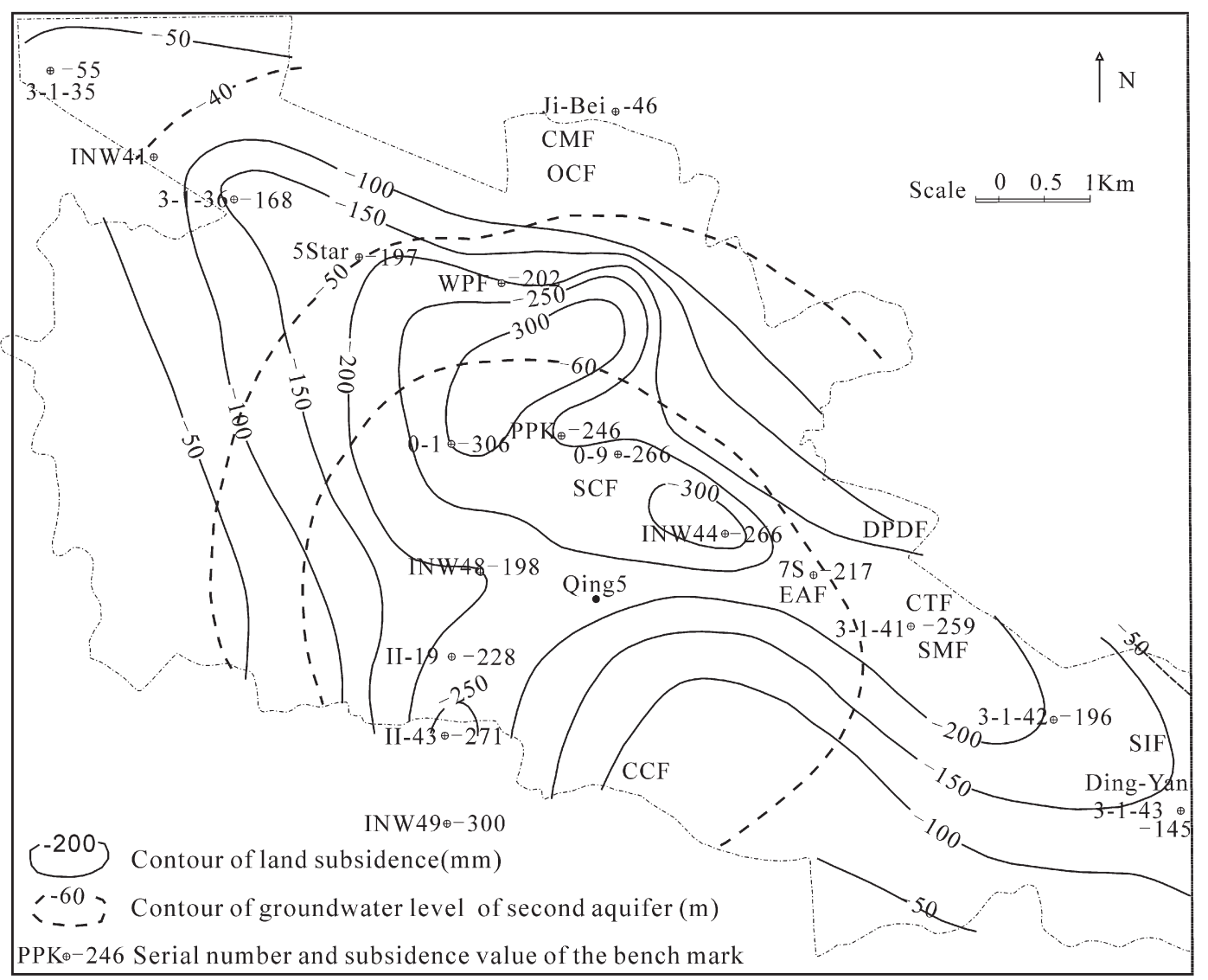

Fig. 5. Contour of land subsidence in Changzhou from 1979 to 1983 and groundwater level in CA2 in 1983.

water level "rises" resulting in a reduced clearance beneath bridges, inaccurate readings on flood warning benchmarks, and lowered elevation of flood preventive dikes. During the once in 100 years flood in 1991, Changzhou City was flooded; $95 \%$ of the inundated area was in the zone with excessive groundwater extraction, and the floodwater was $1.5 \mathrm{~m}$ deep at the trough centre; when the first flood occurred, the

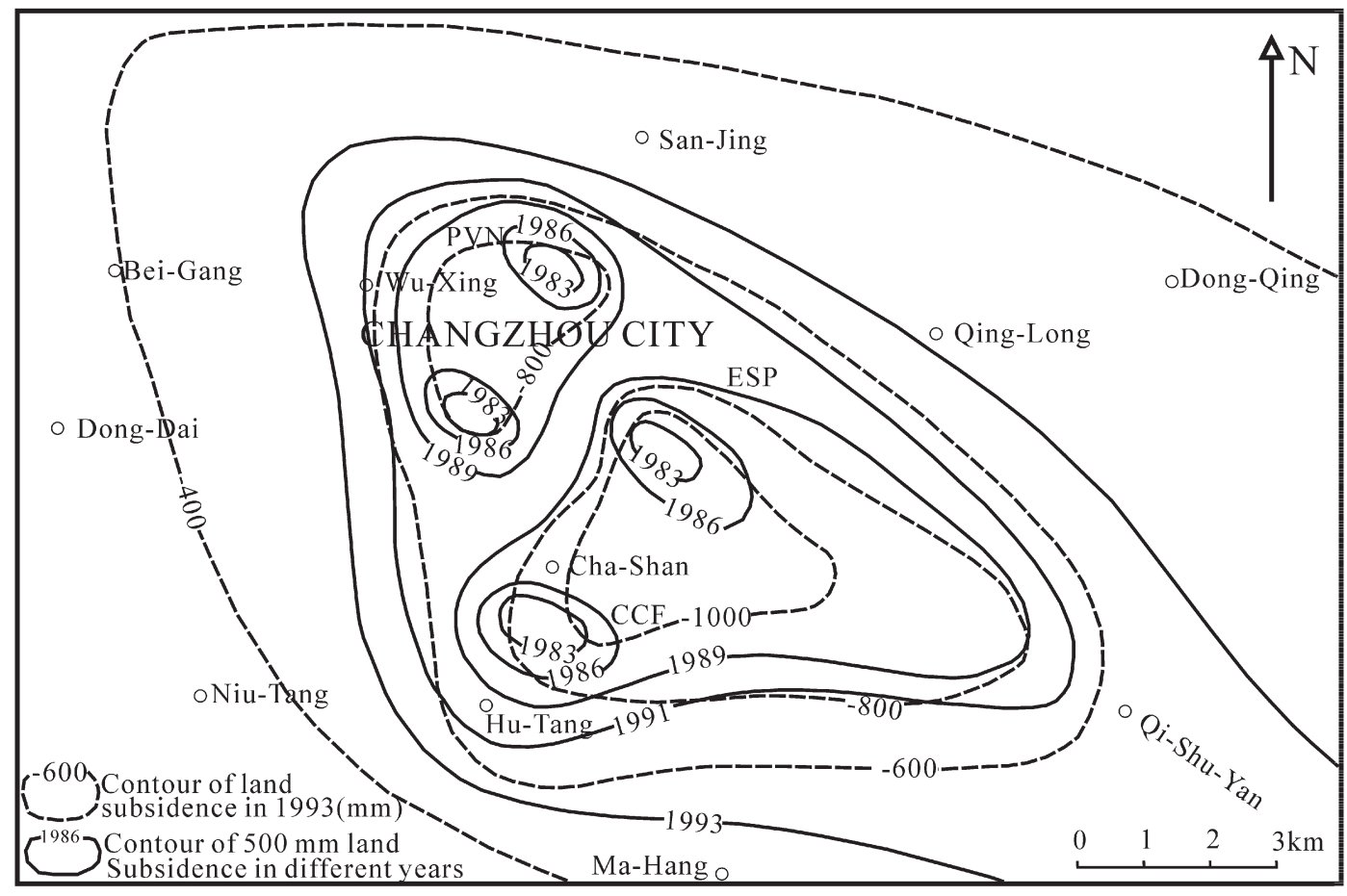

Fig. 6. Contour of land subsidence in Changzhou from 1983 to 1993. 


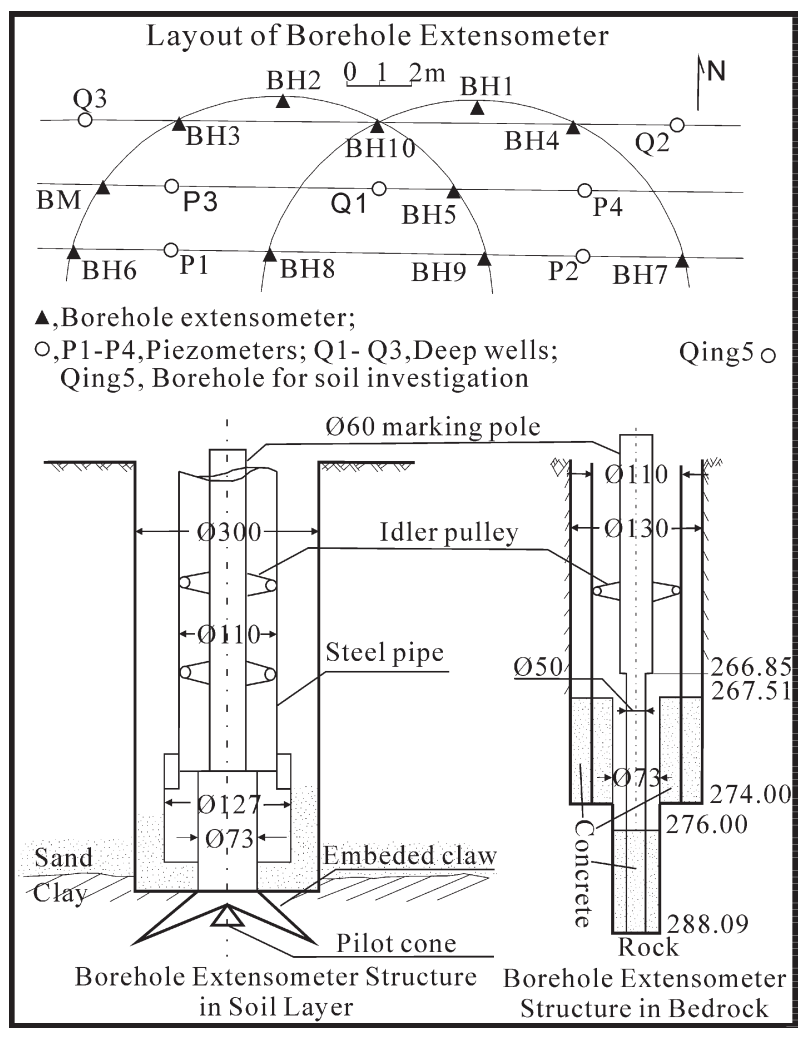

Fig. 7. Plan layout and installation details of borehole extensometers.

water level at high tide was $5.35 \mathrm{~m}$ in the Grant Canal that is similar to the $5.33 \mathrm{~m}$ water level in 1974 when no inundation occurred. In 1999 , the elevation of flood preventive dikes was set at $5.8 \mathrm{~m}$, which is
Table 1

Strata compression measured by borehole extensometers in Changzhou City from January 1984 to December 2002

\begin{tabular}{|c|c|c|c|c|}
\hline $\begin{array}{l}\text { BH no.: Depth } \\
(\mathrm{m})^{\mathrm{a}}\end{array}$ & $\begin{array}{l}\text { Stratum no.: } \\
\text { Namename }^{\text {b }}\end{array}$ & $\begin{array}{l}\text { Zone } \\
\text { no. }\end{array}$ & $\begin{array}{l}\text { Compression, } \\
\mathrm{mm}\end{array}$ & $\begin{array}{l}\text { Percentage of } \\
\text { total, \% }\end{array}$ \\
\hline \multicolumn{5}{|l|}{ BM: 0.00} \\
\hline BH1: 5.98 & 1st: UCA & 1 & 16.83 & 2.50 \\
\hline BH2: 19.09 & 2nd: CA1 & & & \\
\hline ВН3: 39.19 & 3rd: aquitard & & & \\
\hline BH4: 71.84 & 4th: aquitard & 2 & 367.04 & 54.69 \\
\hline BH5: 92.66 & 5th: aquitard & & & \\
\hline BH6: 109.99 & 6th: CA2 & 3 & 79.11 & 11.77 \\
\hline BH7: 118.50 & 7th: aquitard & 4 & 208.56 & 31.03 \\
\hline BH8: 144.78 & 8th: CA3 & & & \\
\hline Bedrock: 163.8 & 9th: CA3 & & & \\
\hline \multicolumn{3}{|c|}{ Total land subsidence } & 672.06 & 100 \\
\hline
\end{tabular}

${ }^{a}$ Initial depth of borehole extensometer with reference to ground surface.

b The 1 st stratum, UCA, is monitored by $\mathrm{BM}$ and $\mathrm{BH} 1$; the 2 nd is by $\mathrm{BH} 1$ and $\mathrm{BH} 2$, and so on.

$280 \mathrm{~mm}$ higher than the highest tide in 1991 (Zhou, 1999). Land sub sidence may endanger the efficiency of such flood preventive facilities.

\section{Changzhou City land subsidence monitoring station}

A land subsidence monitoring station, which is the first of its kind in Jiangsu Province, was established at the site of State Cotton Factory (SCF) in Changzhou City in 1983 to investigate the relationship between land subsidence and groundwater extraction and the compression of different strata. The station includes 11 borehole extensometers, four piezometers and three deep wells. Of the 11 extensometers, BM was installed at the ground surface as a reference benchmark, $\mathrm{BH} 1$ to $\mathrm{BH} 9$ in different stratigraphical depths in Quaternary and BH10 in the sound bedrock at a depth of $288.09 \mathrm{~m}$. Fig. 7 shows the layout of the station and installation details of borehole extensometers. The soil stratigraphy and
$\gamma\left(\mathrm{kN} / \mathrm{m}^{3}\right)$

PL
$\mathrm{P}_{\mathrm{c}}(\mathrm{kPa})$

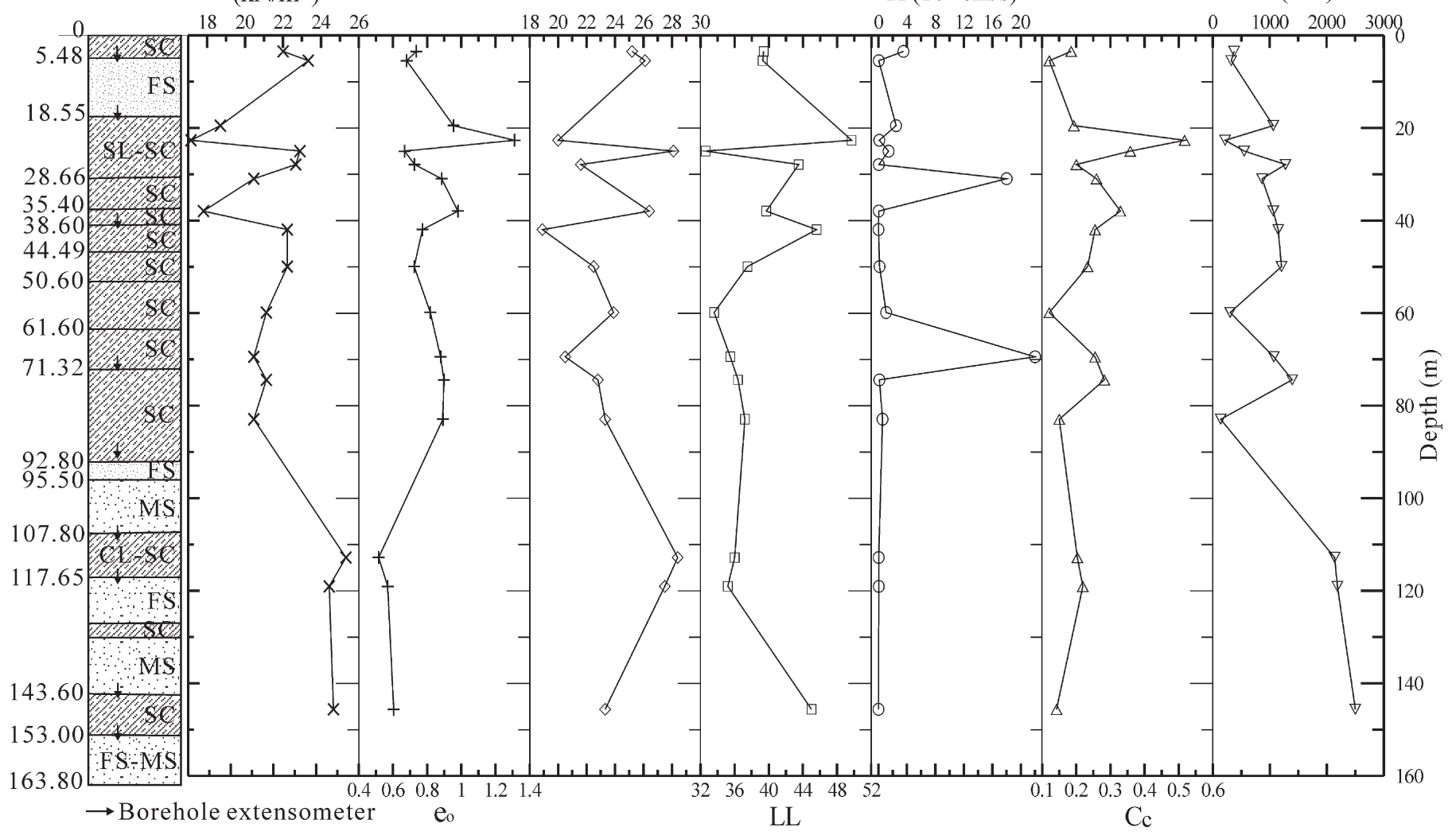

Fig. 8. Soil stratigraphy and properties at the borehole extensometer site (The legends of soils are the same as in Fig. 2). 
Year

1984198619881990199219941996199820002002

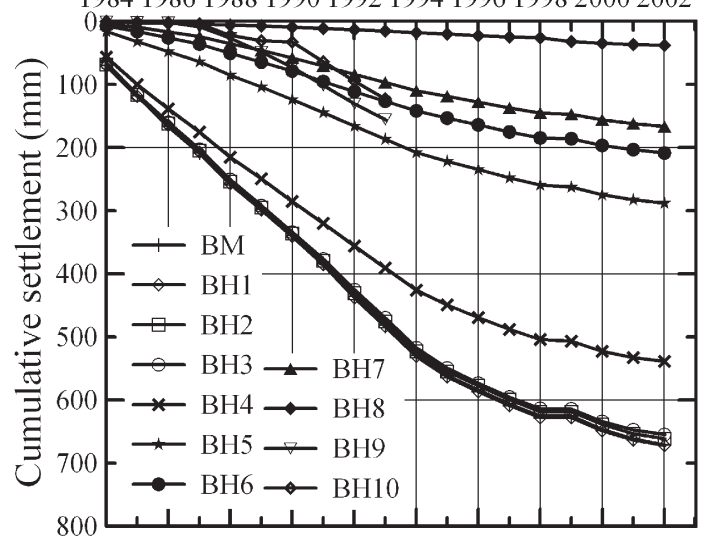

Fig. 9. Settlements measured by borehole extensometers from 1984 to 2002.

properties were determined from the borehole Qing 5 drilled to a depth of $163.0 \mathrm{~m}$. Unit weight $\gamma$, void ratio $e_{\mathrm{o}}$, plastic limit $P_{\mathrm{L}}$, liquid limit $L_{\mathrm{L}}$, hydraulic conductivity $k$, compression index $C_{\mathrm{c}}$ and preconsolidation stress $P_{\mathrm{c}}$ at various depths were tested and are depicted in Fig. 8.

Quaternary sediments at the site are divided into four zones, or depth intervals, and nine strata according to the aquifer and aquitard structure as tabulated in Table 1 . A borehole extensometer was in stalled at every interface of the nine strata as shown on the stra tigraphy in Fig. 8, so settlements of all interfaces can be measured. Then, the strata compression and strain can be computed.

\section{Characteristics of strata compression in Changzhou}

Fig. 9 shows the settlements measured by borehole extensometers from 1984 to 2002. The settlements from BM and BH1 to BH3 were clustered, indicating that the shallow strata in the first zone contributed a little to the land subsidence. Why BH9 and BH10 failed is yet to be investigated. Below is a detailed discussion and analysis on the characteristics of the strata compression according to the strata number in Table 1.

\subsection{Deformation of the first zone: UCA, CA1 and the stratum underlying CA1}

The first zone is in the depth interval from the ground surface to 39.19 m deep and it may comprise aquifers UCA and CA1 and aquitards overlying and underlying CA1. Its compression is characterised by

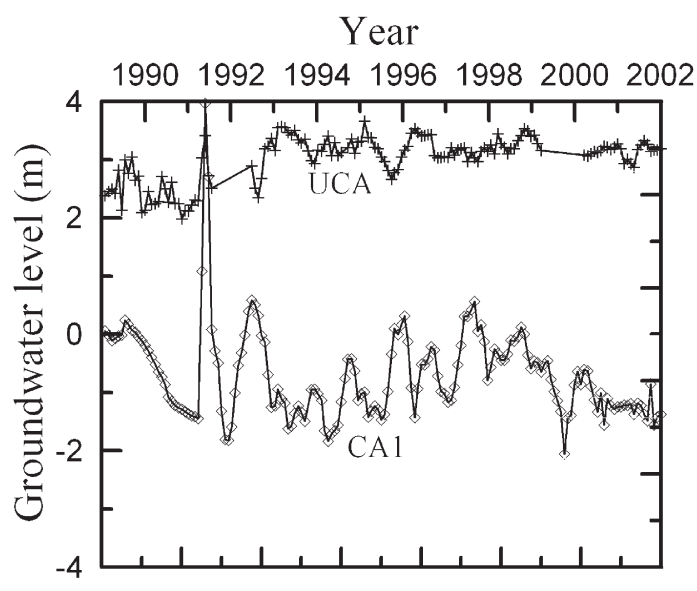

Fig. 11. Groundwater level in UCA and CA1 from 1989 to 2002.

cyclic compression elastic expansion as shown in Fig. 10. This zone constitutes the $1 \mathrm{st}, 2$ nd and 3rd layers.

The 1 st layer, $0 \mathrm{~m}$ to $5.98 \mathrm{~m}$, is UCA. As shown in Fig. 10, the total deformation of this layer was an elastic expansion of about $1.0 \mathrm{~mm}$ from 1984 to 2002. This aquifer is recharged by surface water. Since the groundwater in UCA is not utilised, its average watertable remains around $3.0 \mathrm{~m}$, seasonally fluctuating between $2.0 \mathrm{~m}$ to $4.0 \mathrm{~m}$ as shown in Fig. 11. The cyclic compression elastic expansion is a response to the discharge and recharge. Obviously, two floods in this area in 1991 and 1998, respectively, affected its deformation; an elastic expansion of $1.23 \mathrm{~mm}$ was observed in UCA during the 1991 flood (Fig. 10).

Why did the UCA demonstrate an overall elastic expansion from 1984 to 2002? The deformation of UCA is mainly considered as an elastic response to the seasonal watertable change, which is evident by the agreement between the deformation and groundwater move ment in Figs. 10 and 11, respectively. However, we may need to incorporate the effect of land subsidence. From 1984 to 2002, the land subsided $672 \mathrm{~mm}$, so the effective stress in UCA was reduced $6.72 \mathrm{kPa}$. Such an unloading would contribute an extra elastic expansion. This interpretation is substantiated by the observation that the strong elastic expansion from 1987 to 1993 in Fig. 10 coincided with the aggressive land subsidence rate, or the slope of the BM curve in Fig. 9 during the same period.

The 2nd layer, $5.98 \mathrm{~m}$ to $19.09 \mathrm{~m}$, is aquifer CA1 of fine sand, and its cumulative compaction was $10.29 \mathrm{~mm}$. As the aquitard between UCA and CA1 is discontinuous, the deformation of CA1 is affected by both the discharge of groundwater and recharge of surface water. The de formation curve fluctuates consistently, and the overall is continuous

\section{Year}

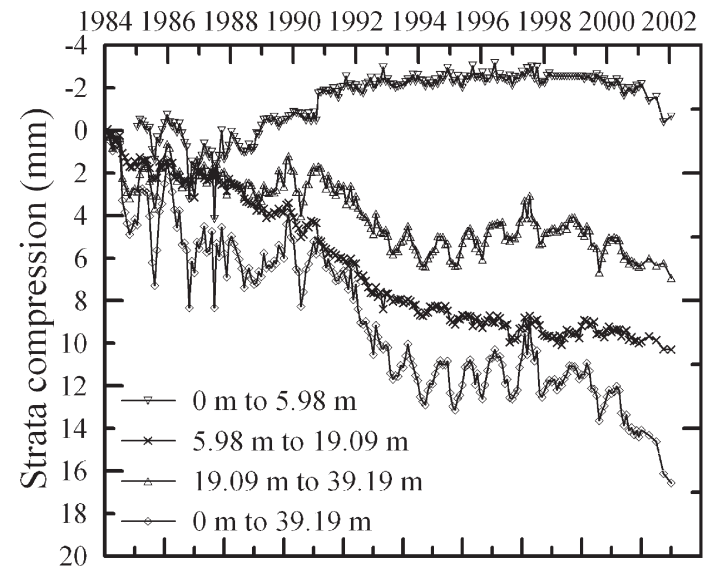

Fig. 10. Strata compression of the first zone $(0 \mathrm{~m}-39.19 \mathrm{~m})$.
Year

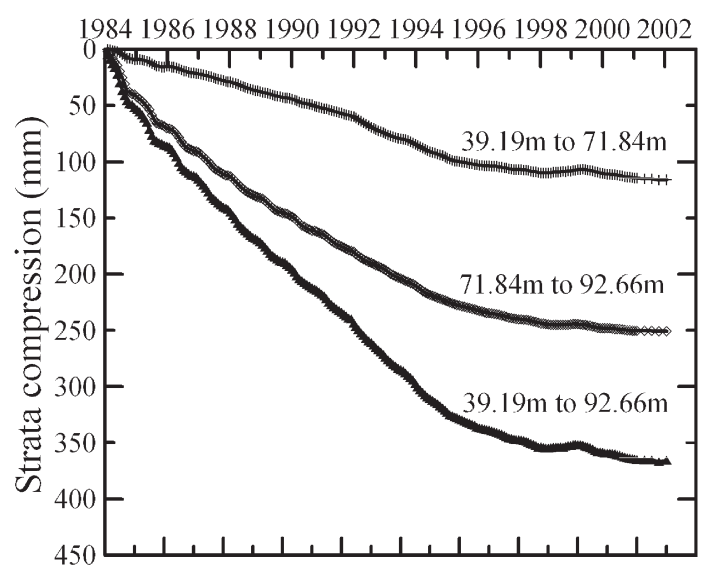

Fig. 12. Strata compression of the second zone (39.19 m-92.66 m). 
Year

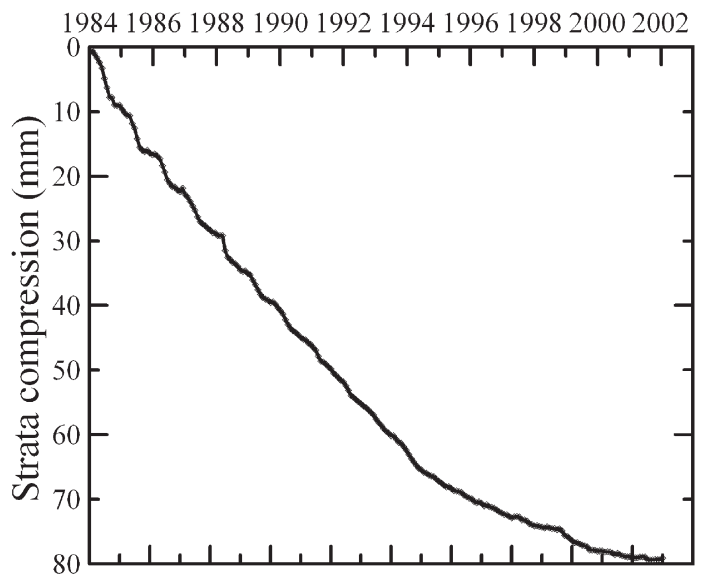

Fig. 13. Strata compression of CA2 (92.66 m-109.99 m).

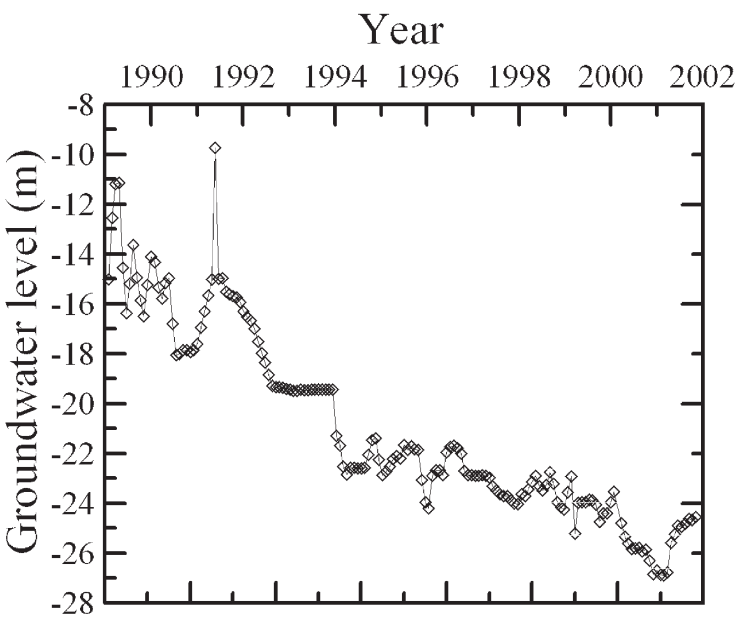

Fig. 15. Groundwater level in CA3 from 1989 to 2002. compression (Fig. 10). A comparison of CA1 and UCA curves shows that their rises and falls coincide, which reflects that CA1 is recharged by surface water like UCA. It is evident in Fig. 11 that the water levels in CA1 and UCA were both near the ground surface in the 1991 flood. How ever, the deformation of CA1 and UCA differs. CA1 was consistently compacted at about $1.0 \mathrm{~mm} /$ year from 1984 to 1986 and from 1987 to 1993, and at about $0.3 \mathrm{~mm} /$ year from 1993 to 2002. In contrast, UCA demonstrated a consistent elastic expansion from 1987 to 1998 and an overall elastic expansion from 1984 to 2002.

The 3rd layer, $19.09 \mathrm{~m}$ to $39.19 \mathrm{~m}$, is the aquitard of silty clay underlying CA1. Its total compression is $6.93 \mathrm{~mm}$ and primarily affected by the fluctuation of groundwater in CA1. The deformation is correlated to two floods in 1991 and 1998 during which the layer was not compressed but rebounded. For example, during the flooding in 1991, the layer rebounded $0.16 \mathrm{~mm}$ that retreated several days later when the flood withdrew. As the effective stress in this depth interval is far less than its preconsolidation stress in Fig. 8, the clay was overconsolidated. From the viewpoint of consolidation, it is at a state of reloading, or a small magnitude elastic compression (Holzer, 1981). Once the watertable recovers, creating an unloading process, its compression may stop and rebound accordingly (see Figs. 10 and 11).

Comparing the curves of the 2nd and 3rd layers in Fig. 10, both were consistently compressed at a similar rate from 1991 to 1993, corres ponding to the continuous groundwater drawdown in CA1 since 1991 (Fig. 11). It is interesting to notice the different deformations since then. Though both layers experienced the same effective stress variation in CA1, the 3rd layer that is the aquitard underlying CA1 had an overall

Year

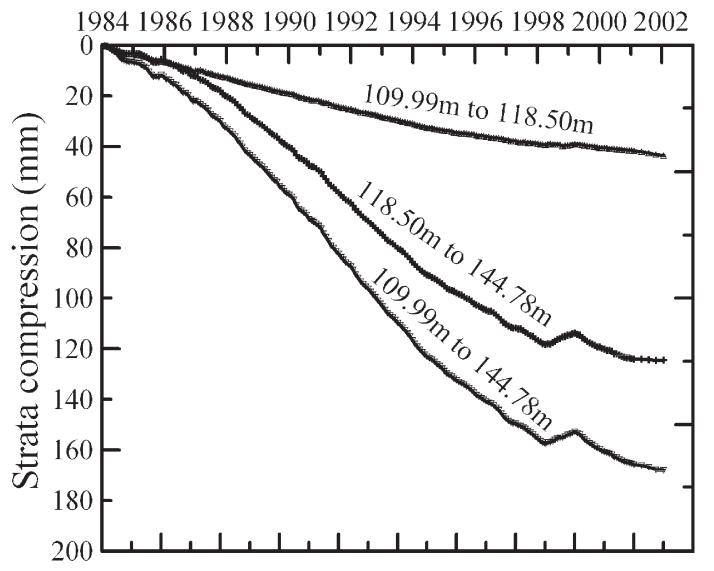

Fig. 14. Strata compression of the 7th and 8th strata (109.99 m-144.78 m). elastic expansion of $2.0 \mathrm{~mm}$ from 1995 to 1998. The aquitard demonstrated strong elastic expansions that exceeded the previous years' highs in 1986,1990,1996 to 1998, but the aquifer rarely rebounded to this degree and exhibited consecutive lower lows. What contributes to the difference? The aquitard of hard clay might behave more elastically under the cyclic loading unloading that was less than its preconsolidation stress, while the aquifer of fine sand might exhibit more plastic deformation, or creeping. Zhang et al. (2007) conducted an oedometer test using the sand from the aquifers in Changzhou, the test result presented in a double logarithmic plot of strain versus time, demonstrated a creeping characteristic at all stress levels from $50 \mathrm{kPa}$ to $3200 \mathrm{kPa}$. The implication is that the elastic expansion of CA1 was partially offset by the creeping deformation at a lowered effective stress when the watertable went up, while the compression was a summation of the elastic and plastic deformation when the watertable declined.

\subsection{Deformation of the second zone: aquitard overlying CA2}

The second zone, $39.19 \mathrm{~m}$ to $92.66 \mathrm{~m}$, is the aquitard overlying CA2 and it comprises silty clay. Its compression is attributed to the con solidation of clay. This zone constitutes the 4th layer (39.19 $\mathrm{m}$ to $71.84 \mathrm{~m}$ ) and the 5th (71.84 $\mathrm{m}$ to $92.66 \mathrm{~m}$ ).

Although the 5th layer is thinner than the 4 th, its compression is about twice that of the 4 th as shown in Fig. 12. As there was a large groundwater drawdown of $75 \mathrm{~m}$ in CA2 but no significant drawdown in CA1 (see Fig. 4 and Fig. 11), the excess pore water pressure in the 4th and 5 th layers would be induced by the effective stress increase in CA2, and the excess pore water would mainly drain towards CA2. Apparently, the closer to CA2, the higher the excess pore water pressure and the faster dissipation of excess pore water. It is evident that the strain increment is 0.012 in the 5 th layer versus 0.0036 in the 4th.

Correlating the compression (Fig. 12) to the groundwater level of CA2 (Fig. 4), the 4th layer was linearly compressed from 1984 to 1992 when the water level steadily and cyclically declined until 1991. The annum compression rate, or the slope of the deformation curve increased from 1992 to 1995 when the groundwater drawdown accelerated from 1991 to 1994 . The curve has eventually flattened since 1996 as the ground water has recovered since 1994 . The time lag is approximately one to two years. As the clay consolidates, the void ratio, compression index and coefficient of hydraulic conductivity decrease and the strata compressibility decreases under the same load. This may be substan tiated by the gradual slowdown of the compression rate of the 5th layer corresponding to the drawdown from 1984 to 1994 . Chen et al. (2003) numerically modelled the change of porosity and hydraulic conductivity of the soft clay underlying CA2 in Suzhou City, and the simulated results 


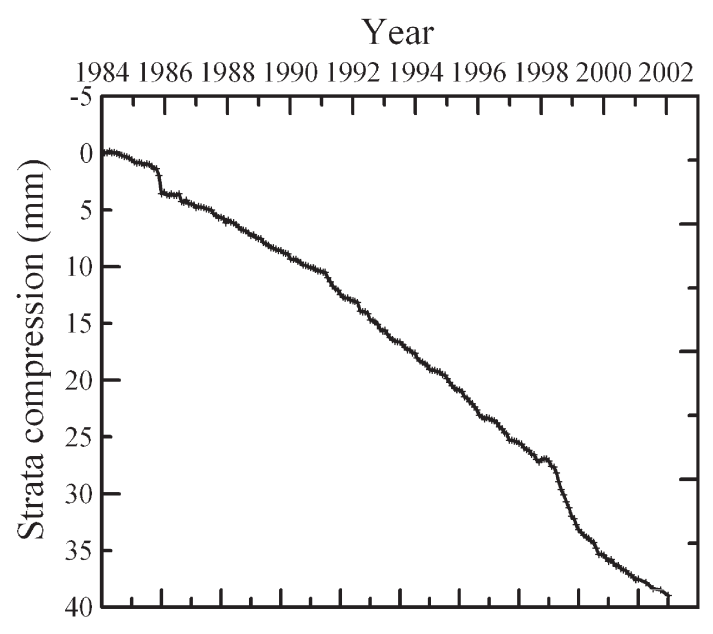

Fig. 16. Strata compression of the 9 th stratum (144.78 m-163.8 m).

from 1983 to 1998 confirmed a consistent cyclic decline of both parameters.

\subsection{Deformation of the third zone: CA2}

The third zone, or the 6th layer, is CA2 (92.66 $\mathrm{m}$ to $109.09 \mathrm{~m}$ ) and it comprises fine and medium sand. The driving force for the compaction of CA2 is again the groundwater drawdown in CA2. As depicted in Fig. 13, the stratum compaction was slowed down since 1994 from about $6 \mathrm{~mm} /$ year to less than $2 \mathrm{~mm} / \mathrm{year}$, corresponding to the groundwater recovery in CA2 since 1994. As shown in Fig. 4, ground water in CA2 continuously declined from $55 \mathrm{~m}$ in 1981 to $76 \mathrm{~m}$ in 1994, but it steadily recovered to $56 \mathrm{~m}$ until 2003 because of the enforcement of restrictions on groundwater withdrawal since 1994. Nevertheless, the permanent compression was $79.11 \mathrm{~mm}$, and it is expected to increase at a gradually lowered rate due to creeping (Zhang et al., 2007). The creeping deformation appears to be completely overtaking the elastic expansion under a higher stress level with re ference to CA1 (Fig. 10), so the compression curve does not really deli neate a rebounding but a flattening when the groundwater seasonally recovers.

\subsection{Deformation of the fourth zone: the strata underlying CA2}

The fourth zone is at the depth interval from $109.09 \mathrm{~m}$ to $163.8 \mathrm{~m}$ and it comprises the 7th to 9th layers. The 7th layer, $109.99 \mathrm{~m}$ to $118.50 \mathrm{~m}$, is the aquitard between CA2 and CA3 and it comprises clay and silty clay. The 8th layer, $118.50 \mathrm{~m}$ to $144.78 \mathrm{~m}$, is part of CA3 of fine to medium sand with a clay seam. The 9 th layer, $144.78 \mathrm{~m}$ to $163.80 \mathrm{~m}$, is the other part of CA3.

As shown in Fig. 14, the compression of the 7th and 8th layers is $43.55 \mathrm{~mm}$ and $124.39 \mathrm{~mm}$, respectively. Nevertheless, their strain increments are very close, 0.0051 and 0.0047 , respectively. The compression of the 7th layer was very linear from 1984 to 1994 due to groundwater drawdown in both CA2 and CA3; a slight ease from 1994 to 1999 might reflect an elastic expansion resulting from the groundwater recovery in CA2 (Fig. 4); a recovery of the compression rate since 1999 might be caused by a further drawdown in CA3 (Fig. 15). After a small compression rate from 1984 to 1986, the compression rate of the 8th layer increased to about $10 \mathrm{~mm} /$ year between 1987 and 1994 when the groundwater in CA3 steadily declined, slightly eased from 1994 to 1997, and flattened after 1998. There was a remarkable elastic expansion in the 8th layer through the entire year of 1998, cor responding to the groundwater level rebound in CA3.

The upper part of the 9th layer consists of silty clay and the lower part is fine to medium sand; BH9 was installed at the interface of the upper and lower parts. However, since BH9 failed, they have been categorized into the 9th layer. Due to the failure of BH10, the crust subsidence caused by neotectonic movement could not be deducted from the 9th layer, and it is reported at $0.38 \mathrm{~mm} / \mathrm{year}$ in the Yangtze River Delta region (Zuo et al., 1993). Fig. 16 is the compression of the 9th layer, which depicts a gradually increased compression rate in three phases, namely, 1984 to 1986, 1986 to 1992 and 1992 to 1999, somewhat similar to the 8 th layer.

As summarized in Table 1, land subsidence in Chanzhou from 1984 to 2002 was mainly contributed to by the aquitard overlying CA2 whose compression of $367.04 \mathrm{~mm}$ is $54.69 \%$ of the land subsidence, followed by the deep aquifers CA3 and CA2.

\section{Conclusions}

Land subsidence caused by groundwater extraction was first observed in the 1960s in Changzhou City, and the cumulative subsidence reached $1800 \mathrm{~mm}$ over five decades. The land subsidence rate was relatively small before 1970 with a cumulative subsidence of less than $300 \mathrm{~mm}$. The maximum land subsidence rate occurred in the late 1970s and 1980s, with a recorded maximum annual subsidence of $147 \mathrm{~mm}$. The average annual subsidence was $59.63 \mathrm{~mm}$ from 1979 to 1983 and $57.94 \mathrm{~mm}$ from 1984 to 1990 . Since the city government enforced restrictions on groundwater extraction in 1995, the ground water in the second confined aquifer was recovered by $20 \mathrm{~m}$ to the level in early 1981. Consequently, the land subsidence rate gradually decreased, the average annual subsidence was $27.72 \mathrm{~mm}$ by 2002 and it was $9.9 \mathrm{~mm}$ in 2002 .

The discussion and analysis on strata compression from 1984 to 2002 are based on the settlement data measured by borehole extensometers at the interfaces of nine strata with reference to the stratigraphy, soil properties, variations in groundwater drawdown and extraction rate and literature on similar situations. It is concluded that the compression of strata varies significantly as summarized below.

The compression of shallow strata ( $0 \mathrm{~m}$ to $39.19 \mathrm{~m}$ ) is characterised by cyclic compression elastic expansion caused by the seasonal fluctuation of groundwater. As the compression of $16.83 \mathrm{~mm}$ is small, the elastic expansion that resulted from the reduction of effective stress caused by the lowered elevation due to land subsistence should be considered in the analysis. The deformation of three layers in this zone differs remarkably. The 1st layer, UCA, became slightly thicker from 1984 to 2002. The 2nd layer, CA1, was predominantly compressed with seasonal elastic expansions, which might include a significant creeping deformation (Zhang et al., 2007). The 3rd layer, aquitard underlying CA1, behaved more elastically than CA1 under the cyclic loading unloading that was less than its preconsolidation stress.

The aquitard overlying CA2 (39.19 $\mathrm{m}$ to $92.66 \mathrm{~m}$ ) was the major compressive strata whose compression of $367.04 \mathrm{~mm}$ is $54.69 \%$ of the land subsidence. The compression was mainly resulted from the consolidation of the aquitard due to a large groundwater drawdown in CA2. It is evident that the compression closely followed the variation of groundwater level in CA2 with a time lag of one to two years. As the groundwater level in CA2 recovered from $76 \mathrm{~m}$ in 1994 to $56 \mathrm{~m}$ in 2003, the compression has been flattened since 1996.

The compaction rate of CA2 (92.66 $\mathrm{m}$ to $109.99 \mathrm{~m}$ ) was reduced from $6.0 \mathrm{~mm} /$ year to less than $2.0 \mathrm{~mm} / \mathrm{year}$, corresponding to the ground water recovery in CA2 since 1994. The compression was $79.11 \mathrm{~mm}$ from 1984 to 2002, and it is expected to increase at a gradually lowered rate due to creeping (Zhang et al., 2007). The creeping deformation appears to be completely overtaking the elastic expansion under a higher stress level with reference to CA1.

The compression of the aquitard between CA2 and CA3 (109.99 m to $118.5 \mathrm{~m}$ ) was doubly affected by groundwater drawdown in CA2 and $\mathrm{CA} 3$.

CA3 (118.5 $\mathrm{m}$ to $163.8 \mathrm{~m}$ ) experienced about 20 years' steady compaction following the groundwater drawdown in CA3. CA3 might 
become a major compressive stratum if the groundwater drawdown continues in CA3 since it is not evident that its primary consolidation is completed. One factor that should be investigated in the future is to which degree groundwater migrates through the aquitard between CA2 and CA3.

\section{Acknowledgements}

The authors sincerely thank Geological Survey of Jiangsu Province for their support, Dr. Noppadol Phien wej of Asian Institute of Technology and an anonymous reviewer for their valuable comments and Talia Barrett of University of Ballarat for proof reading the manuscript.

\section{References}

Abidin, H.Z., Djaja, R., Darmawan, D., Hadi, S., Akbar, A., Rajiyowiryono, H., Sudibyo, Y, Meilano, I., Kasuma, M.A., Kahar, J., Subarya, C., 2001. Land subsidence of Jakart (Indonesia) and its geodetic monitoring system. Natural Hazards 23, 365-387.

Chen, C.X. Pei, S.P., Jiao, J. . 2003. Land subsidence caused by groundwater exploitation in Suzhou City, China. Hydrogeology Journal 11, 275-287.

Endo, T., 1992. Confined groundwater system in Tokyo. Environmental Geology 20 (1) 21-34.

FHEG, 1984. The First Hydrogeology and Engineering Geology, Integrated Reconnaissance and Survey Report on Hydrogeology, Engineering Geology and Environmental Geology in Changzhou City.

FHEG, 1989. The First Hydrogeology and Engineering Geology, Report of Hydrogeology and Environmental Geology Monitoring in Changzhou City.

GSJP, 2004. Geological Survey of Jiangsu Province, Report of Geological Hazards Investigating and Prevention and Remediation Planning. Nanjing.
Holla, L., Barclay, E., 2000. Mine Subsidence in the Southern Coalfield, NSW, Australia. Sydney, New South Wales Department of Mineral Resources.

Holzer, T.L., 1981. Preconsolidation stress of aquifer systems in areas of induced land subsidence. Water Resources Research 17 (3), 693-703.

Holzer, T.L., Johnson, A.I., 1985. Land subsidence caused by ground water withdrawal in urban areas. GeoJournal 11 (3), 245-255.

Hu, R.L., Wang, S.J., Lee, C.F., Li, M.L., 2002. Characteristics and trends of land subsidence in Tanggu, Tianjin, China. Bulletin of Engineering Geology and the Environment 61 (3), 213-225.

Hu, R.L., Yue, Z.Q., Wang, L.C., Wang, S.J., 2004. Review on current status and challenging issues of land subsidence in China. Engineering Geology 76 (1-2), 65-77.

Li, C.J., Tang, X.M., Ma, T.H., 2006. Land subsidence caused by groundwater exploitation in the Hangzhou-Jiaxing-Huzhou Plain, China. Hydrogeology Journal 14 $1652-1665$.

Nutalaya, P., Chandra, S., Balasubramaniam, A.S., 1986. Subsidence of Bangkok Clay due to Deep Well Pumping and Its Control through Artificial Recharge. Proc. of the 3rd International Symposium on Land Subsidence, International Association of Hydrological Sciences, Wallingford.

Phien-wej, N., Giao, P.H., Nutalaya, P., 2006. Land subsidence in Bangkok, Thailand. Engineering Geology 82 (4), 187-201.

Singh, M.M., 1992. Mine subsidence. In: Hartman, H.L. (Ed.), SME Mining Engineers Handbook, pp. 938-971.

Wang, G.Y., You, G., Shi, B., Yu, J., Li, H.Y., Zong, K.H., 2008. Earth fissures triggered by groundwater withdrawal and coupled by geological structures in Jiangsu Province, China. Environmental Geology DOI 10.1007/s00254-008-1390-1.

Zhang, Y., Xue, Y.Q., Wu, J.C., Ye, S.J., Wei, Z.X., Li, Q.F., Yu, J., 2007. Characteristics of aquifer system deformation in the Southern Yangtze Delta, China. Engineering Geology 90, 160-173.

Zhou, T.H., 1999. 1999 Changzhou City Flood Prevention Plan, Changzhou City Flood Prevention Office.

Zhu, Q., Gao, Z., Guo, J., 1993. Earth fissures and their genesis analysis in Dongting, Wuxi. Chinese Journal of Seismology 3, 31-35.

Zuo, H., Liu, T.Z., Lin, X.H., 1993. Economic benefit risk assessment of controlling land subsidence in Shanghai. Environmental geology 21 (4), 208-211. 